\title{
TARGETTING THE 3BGQ - PIM1 KINASE INTERACTION WITH A SERIES OF NOVEL DITHIOCARBAMATE SUBSTITUTED 2- OXOINDOLE DERIVATIVES - IN SILICO STUDIES
}

\author{
3BGQ - PIMI KINAZ ETKİLEŞIMINİ HEDEF ALAN YENİ DITTIYOKARBAMAT ILLE \\ SÜBSTITÜ̈E 2-OKSOINDOL TÜREVLERININ INN SILLIKO ÇALIŞMALARI
}

\section{Muni Sireesha SUNKARA ${ }^{1}$ (D), Dharani ANNEPALLY ${ }^{2}$ (D), Donna Kanthi BITLA ${ }^{2}$ (D), Sushma BOPPY $^{2} \mathbb{D}$, Pallavi CHIDURALA ${ }^{2} \mathbb{D}$, Jhansi CHILUKA ${ }^{2} \mathbb{D}$, Saritha Jyostna TANGEDA ${ }^{2 *}(\mathbb{D})$}

\author{
${ }^{1}$ Osmania University, Sarojini Naidu Vanita Pharmacy Maha Vidyalaya, Department of \\ Pharmacoinformatics, 500007, Hyderabad, India \\ ${ }^{2}$ Osmania University, Sarojini Naidu Vanita Pharmacy Maha Vidyalaya, Department of
}

Pharmaceutical Chemistry, 500007, Hyderabad, India

\begin{abstract}
Objective: Cancer is the major cause of mortality in most of the developing countries. Enormous chemotherapeutic agents developed are still need improvements in survival rates and quality of life for cancer patients. Pro-viral Integration site of Moloney murine leukemia virus (PIM1) is a family of serine/threonine kinase, regulated by calcium/calmudulin have been identified as a unique molecular target in oncogenesis. PIM1 has significant role in cell cycle regulation, cell survival, apoptosis, cellular senescence, drug resistance and it is emerging as a potential biomarker in number of human malignancies. Today many interesting PIMI inhibitors are developed and few withdrawn from phase 1 and 2 clinical trials, due to lack of bioavailability and toxicity. Hence the purpose of the present study is to develop more potent and less toxic compounds.

Material and Method: A series of novel 2-oxindoles with dithiocarbamates were designed as PIM1 inhibitors. All molecules were subjected to Molsoft, Molinspiration, Swiss ADME and pkCSM to predict their molecular properties which are important for drug candidate. Further, in order to find the binding affinity of designed molecules with PIM1 kinase protein and to rationalize their anticancer activity, molecular docking study was performed.

Result and Discussion: Results revealed that all designed compounds fulfilled the criteria for good oral bioavailability, low toxicity and the potential inhibitory activities. All of them were docked into active site of
\end{abstract}

\footnotetext{
* Corresponding Author/Sorumlu Yazar: Saritha Jyostna Tangeda e-mail / e-posta: sarithavanita13@gmail.com, Phone / Tel.: +919848928766
} 
PIM1 kinase with AutoDock Vina software. In conclusion, according to the binding energy values, compound 16 and 24 showed equivalent dock score $-9.7 \mathrm{kcal} / \mathrm{mol}$ which are comparable with previously reported compounds AZ1208 and SGI 1776. This finding will help the researchers in the design of a better drug for the treatment of cancer.

Keywords: AutoDock Vina, dithiocarbamate, PIM1 Kinase, QSAR, 2-oxindole

\section{ÖZ}

Amaç: Kanser, gelişmekte olan ülkelerin çoğunda başlıca ölüm nedenidir. Geliştirilen muazzam kemoterapötik ajanların, kanser hastalarının hayatta kalma oranları ve yaşam kaliteleri açısından hala iyileştirilmeleri gerekmektedir. Moloney murin lösemi virüsünün (PIM1) pro-viral entegrasyon bölgesi, kalsiyum/kalmudulin tarafindan düzenlenen bir serin/treonin kinaz ailesidir, onkogenezde benzersiz bir moleküler hedef olarak tanımlanmıştır. PIM1 hücre döngüsü düzenlenmesi, hücre sağkalımı, apoptozu, hücresel yaşlanması ve ilaç direncinde önemli bir role sahiptir ve insan malignitelerinin sayısında potansiyel bir biyobelirteç olarak ortaya çıkmaktadır. Bugün birçok ilginç PIM1 inhibitörü geliştirildi ve biyoyararlanım ve toksisite eksikliği nedeniyle birkaçı faz 1 ve 2 klinik çalışmalardan çekildi. Dolayısıyla bu çalışmanın amacı, daha güçlü ve daha az toksik bileşikler gelişstirmektir.

Gereç ve Yöntem: Ditiyokarbamat içeren bir seri yeni 2-oksindoller PIM1 inhibitörü olarak tasarlandl. Tüm moleküllerin ilaç adayı için önemli olan moleküler özelliklerini tahmin etmek için Molsoft, Molinspiration, Swiss ADME ve pkCSM programları kullanıld. Ayrıca, tasarlanan bileşiklerin PIM1 kinaz proteini ile bağlanma afinitelerini bulmak ve antikanser aktivitelerini rasyonalize etmek için, moleküler yerleştirme çalışmast yapıld $t$.

Sonuç ve Tartışma: Sonuçlar, tasarlanan tüm bileşiklerin iyi oral biyoyararlanım, düşük toksisite ve potansiyel inhibitör aktiviteler için kriterleri karşıladığını ortaya koymaktadır. Tüm bileşiklerin PIMI kinazın aktif bölgesine yerleştirilmesi Auto DockVina yazılımı ile gerçekleştirildi. Sonuç olarak, bağlanma enerjisi değerlerine göre, bileşik 16 ve 24 daha önce bildirilen AZ1208 ve SGI 1776 bileşikleri ile karşılaştırllabilir eşdeğer dock skoru $-9.7 \mathrm{Kcal} / \mathrm{mol}$ gösterdi. Bu bulgu, araştırmacılara kanser tedavisi için daha iyi bir ilacın tasarımında yardımcı olacaktır.

Anahtar Kelimeler: AutoDock Vina, ditiyokarbamat, PIM1 Kinaz, QSAR, 2-oksoindol

\section{INTRODUCTION}

Pro-viral Integration site of Moloney murine leukemia virus (PIM) are a family of serine/threonine kinases of calcium/calmodulin-dependent [1]. PIM kinases include three genes-PIM1, PIM2 and PIM3. They are involved in multiple human cancers including prostate cancer, acute myeloid leukemia, and other hematopoietic malignancies. PIM 1 kinases are unique and divergent from other kinases with greater than $60 \%$ parity amongst each member [2]. PIM 1 kinase play an important role in multiple cellular functions which include cell cycle regulation, cell survival, apoptosis, cellular senescence, and drug resistance [3]. The inhibitors which inhibit or slow the chemical action of PIM 1 kinases include flavonoids, cinnamic acids, Isoxazoloquinoline-3,4diones, benzoisoxazoles, imidazole (1,2-b) pyridazines, most of them are in clinical trials [4]. Although these compounds have exhibited good potency and minimal toxicities in vitro cell lines, their clear toxicity analysis is still being undertaken by researchers worldwide and there is wide scope to develop new leads. Other side, oxindole has emerged as a valuable scaffold in medicinal chemistry possessing diverse range of pharmacological activities [5]. The synthetic oxindole derivatives Sunitinib is marketed anti-cancer agent for gastrointestinal stromal tumors and metastatic renal cell cancer [6]. Further optimization of the 
substituents around the oxindole nucleus resulted in several oxindole based kinase inhibitors that are in clinical trials SU11248, SU5416, SU5614, SU6668, SU14813 and SU4984 [7]. In view of the literature, we designed a novel 2-oxoindole with substitution of dithiocarbamate at $3^{\text {rd }}$ and electron releasing or elctron donating groups at sixth position as shown in fig. 1. Molecular docking can strongly support and help the design of novel, more potent inhibitors by revealing the mechanism of drug-receptor interaction.<smiles>[R]c1ccc2c(c1)NC(=O)C2CSC(=S)N([R7])[14CH]=[13C]</smiles>

$$
\mathbf{N R}^{\mathbf{1}} \mathbf{R}^{\mathbf{2}}=\text { Alkyl/Cycloalkyl /Aralkyl }
$$

Figure 1. General structure of designed 2-oxoindole derivatives as PIM1 inhibitors.

Table 1. Structures and IUPAC names of the designed oxindole derivatives

\begin{tabular}{|l|l|}
\hline $\begin{array}{l}\text { Compound } \\
\text { Code }\end{array}$ & $\begin{array}{l}\text { Chemical Name } \\
\text { (2-oxo-2,3-dihydro-1H-indol- } \\
\text { diethylcarbamodithioate }\end{array}$ \\
\hline 2. & $\begin{array}{l}\text { (2-oxo-2,3-dihydro-1H-indol- } \\
\text { 3-yl)methyl pyrrolidine-1- } \\
\text { carbodithioate }\end{array}$ \\
\hline 3. & $\begin{array}{l}\text { (2-oxo-2,3-dihydro-1H-indol- } \\
\text { 3-yl)methyl piperidine-1- } \\
\text { carbodithioate }\end{array}$ \\
\hline
\end{tabular}


Table 1 (continued). Structures and IUPAC names of the designed oxindole derivatives.

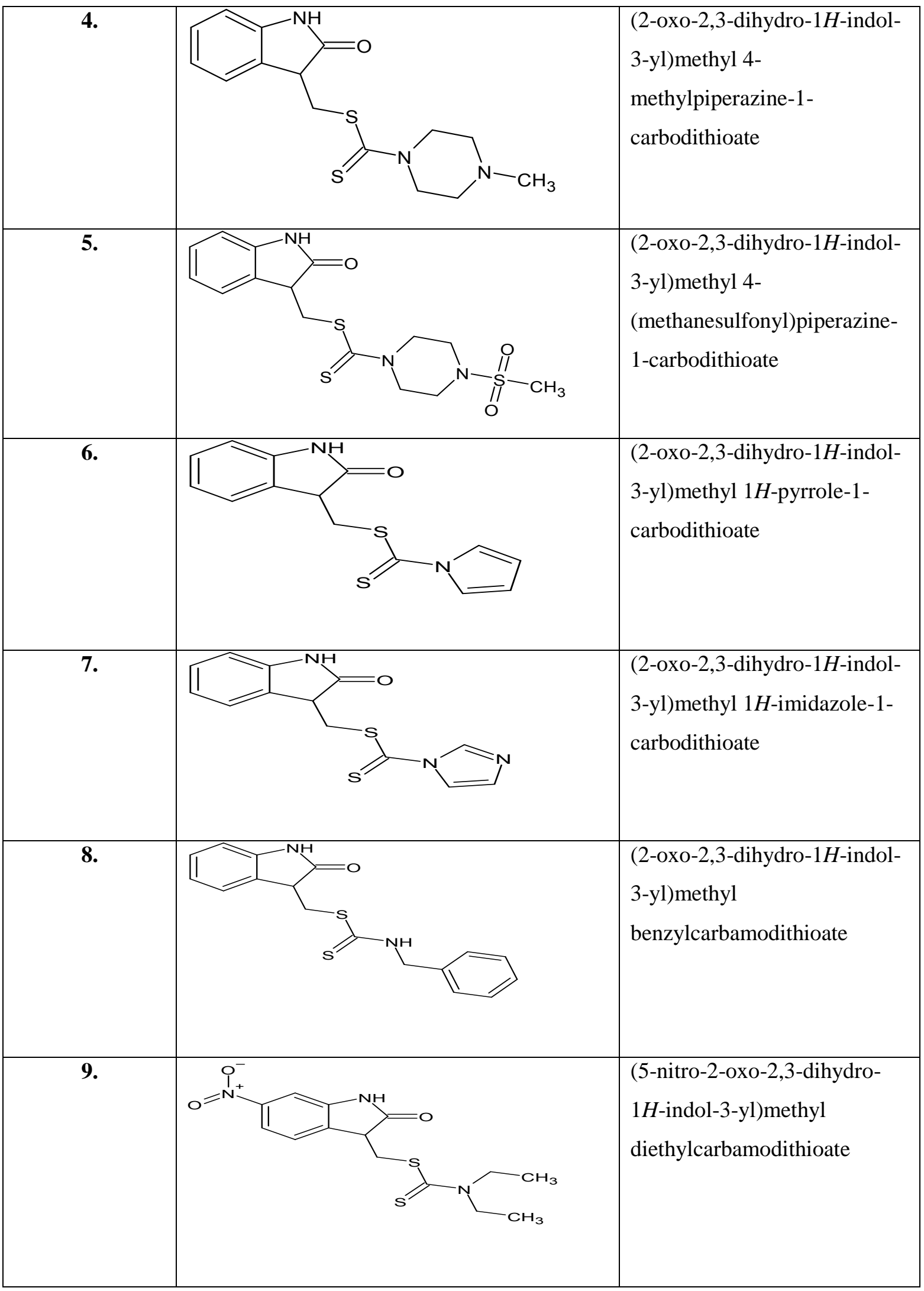


Table 1 (continued). Structures and IUPAC names of the designed oxindole derivatives

\begin{tabular}{|c|c|c|}
\hline 10. & $\mathrm{O}_{+}^{-}$ & $\begin{array}{l}\text { (5-nitro-2-oxo-2,3-dihydro- } \\
1 H \text {-indol-3-yl)methyl } \\
\text { pyrrolidine-1-carbodithioate }\end{array}$ \\
\hline 11. & & $\begin{array}{l}\text { (5-nitro-2-oxo-2,3-dihydro- } \\
1 H \text {-indol-3-yl)methyl } \\
\text { piperidine-1-carbodithioate }\end{array}$ \\
\hline 12. & & $\begin{array}{l}\text { (5-nitro-2-oxo-2,3-dihydro- } \\
\text { 1H-indol-3-yl)methyl 4- } \\
\text { methylpiperazine-1- } \\
\text { carbodithioate }\end{array}$ \\
\hline 13. & & $\begin{array}{l}\text { (5-nitro-2-oxo-2,3-dihydro- } \\
\text { 1H-indol-3-yl)methyl 4- } \\
\text { (methanesulfonyl)piperazine- } \\
\text { 1-carbodithioate }\end{array}$ \\
\hline 14. & & $\begin{array}{l}\text { (5-nitro-2-oxo-2,3-dihydro- } \\
1 H \text {-indol-3-yl)methyl } 1 H \text { - } \\
\text { pyrrole-1-carbodithioate }\end{array}$ \\
\hline
\end{tabular}


Table 1 (continued). Structures and IUPAC names of the designed oxindole derivatives

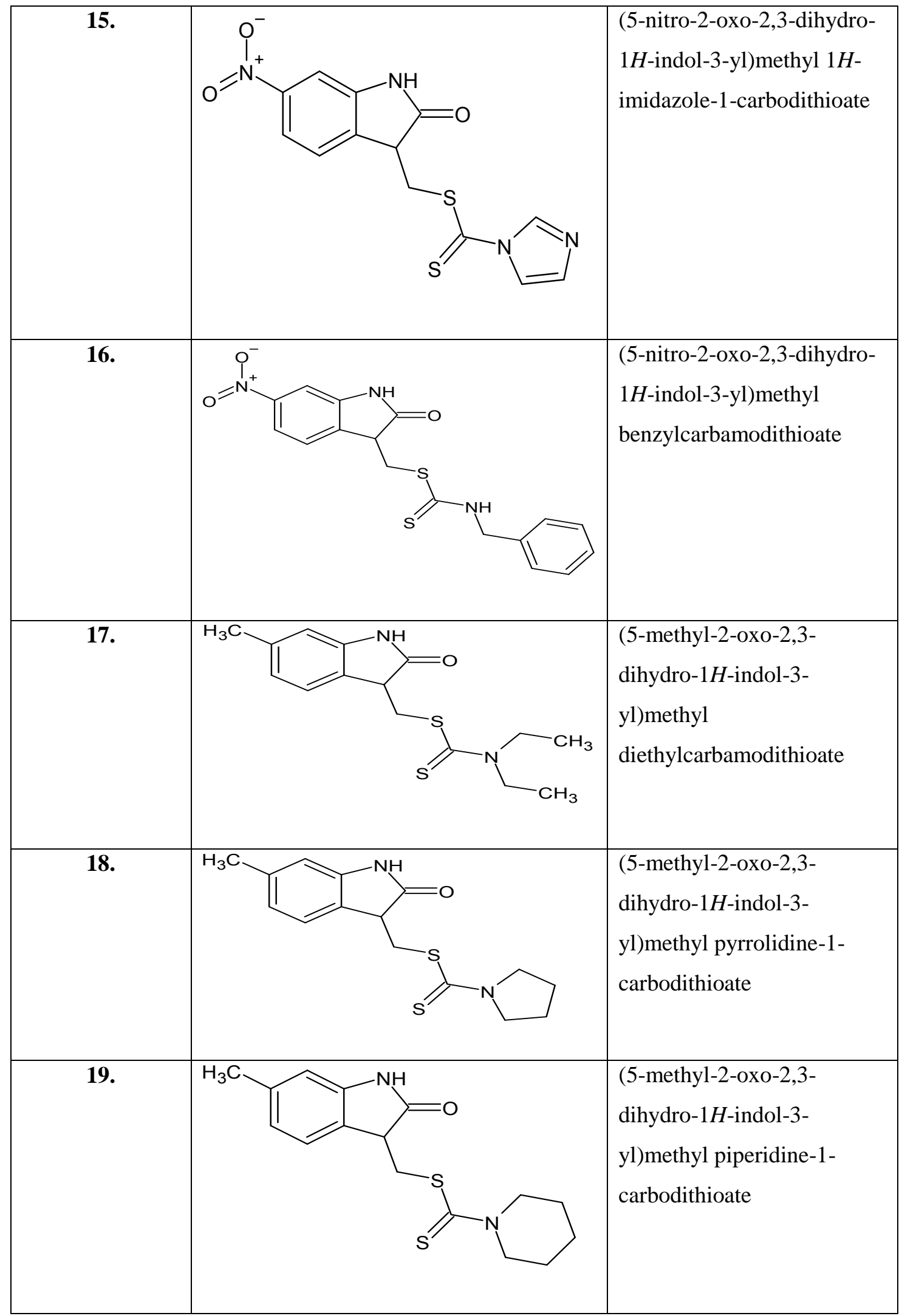


Table 1 (continued). Structures and IUPAC names of the designed oxindole derivatives

\begin{tabular}{|c|c|c|}
\hline 20. & $\mathrm{H}_{3} \mathrm{C} \longrightarrow \curvearrowright \mathrm{NH}_{=}$ & $\begin{array}{l}\text { (5-methyl-2-oxo-2,3- } \\
\text { dihydro-1H-indol-3- } \\
\text { yl)methyl 4- } \\
\text { methylpiperazine-1- } \\
\text { carbodithioate }\end{array}$ \\
\hline 21. & $\mathrm{H}_{3} \mathrm{C} \leadsto$ & $\begin{array}{l}\text { (5-methyl-2-oxo-2,3- } \\
\text { dihydro-1H-indol-3- } \\
\text { yl)methyl 4- } \\
\text { (methanesulfonyl)piperazine- } \\
\text { 1-carbodithioate }\end{array}$ \\
\hline 22. & $\mathrm{H}_{3} \mathrm{C}_{\longrightarrow}$ & $\begin{array}{l}\text { (5-methyl-2-oxo-2,3- } \\
\text { dihydro-1H-indol-3- } \\
\text { yl)methyl } 1 H \text {-pyrrole-1- } \\
\text { carbodithioate }\end{array}$ \\
\hline 23. & $\mathrm{H}_{3} \mathrm{C}_{-}$ & $\begin{array}{l}\text { (5-methyl-2-oxo-2,3- } \\
\text { dihydro-1H-indol-3- } \\
\text { yl)methyl } 1 H \text {-imidazole-1- } \\
\text { carbodithioate }\end{array}$ \\
\hline 24. & $\mathrm{H}_{3} \mathrm{C}-$ & $\begin{array}{l}\text { (5-methyl-2-oxo-2,3- } \\
\text { dihydro-1H-indol-3- } \\
\text { yl)methyl } \\
\text { benzylcarbamodithioate }\end{array}$ \\
\hline
\end{tabular}




\section{MATERIAL AND METHOD}

\section{Molecular Descriptors, Bioactivity Prediction and ADMET Properties}

In the drug discovery process, computational (in silico) enables optimization of lead molecules by comparing absorption, distribution, metabolism, excretion and toxicity (ADMET) properties and screening of molecules [8]. Data sets of 24 molecules have been chosen for this study. The softwares used are SwissADME (Free, CC-BY 4.0 Creative Commons 4.0 International License, Swiss Institute of Bioinformatics, Switzerland), Molsoft (Free, Molsoft LLC, US), Molinspiration Cheminformatics free web services (Slovensky Grob, Slovakia), pkCSM (Free, Bio 21 Institute University of Melbourne, 30 Flemington Rd Parkville, Melbourne, Australia). The molecules were subjected to Swiss ADME; a free web tool to evaluate pharmacokinetics, drug-likeness and medicinal chemistry friendliness of small molecules. This server is useful in the prediction of properties like number of hydrogen bond donor, number of hydrogen bond acceptor, molar refractivity, total polar surface area (TPSA), Lipinski violation [9]. Molsoft; a leading provider of tools, databases and consulting services in the area of structure prediction, structural proteomics, bioinformatics, cheminformatics, molecular visualization and animation and rational drug design. From this server, lop $\mathrm{P}(\mathrm{o} / \mathrm{w})$ values are predicted [10]. Molinspiration; offers broad range of cheminformatics software tools supporting molecule manipulation and processing, including SMILES and SD file conversion, normalization of molecules, generation of tautomer's, molecule fragmentation, calculation of various molecular properties needed in QSAR, molecular modelling and drug design, high quality molecule depiction. This software is used to predict GPCR ligand, ion channel modulator, kinase inhibitor, nuclear receptor ligand, protease inhibitor, enzyme inhibitor [11]. pkCSM (Free, Bio 21 Institute University of Melbourne, 30 Flemington Rd Parkville, Melbourne, Australia); a novel method for predicting and optimizing small molecule pharmacokinetic and toxicity properties which relies on distance-based graph signatures. It predicts their pharmacokinetic (absorption, distribution, metabolism, excretion) and toxicity (ADMET) properties. It helps in the prediction of human intestinal absorption (HIA\%), in vitro skin permeability, in vitro VDss (human), in vitro blood brain barrier permeability and toxicity [12].

\section{Molecular Docking Studies}

The molecular modelling-based approach was adopted to understand the structure of the PIM1 protein along with binding efficiency of various ligand molecules considered for this study. The threedimensional (3D) structure of PIM1 kinase (PDB ID: 3BGQ) was downloaded from Brook heaven Protein Data Bank and saved as a Brookhaven protein data bank file [16]. The 2D structures of ligands were generated from the ACD/Chemsketch Software. The generated ligands cleaned and performed 3D optimization then saved in the MDL Molfile format. The ligands were then converted to a PDB file 
format using the Open Babel chemistry toolbox. AutoDock Vina [18] (Academic version.1.2.0, Molecular Graphics Lab (now CCSB) at The Scripps Research Institute) was used for molecular docking studies. A grid was generated around the co-crystallized ligand. The co-ordinates $(x=-8.298$, $y=40.748, z=0.228$ ) were generated with the help of MGL Tools and Pharmit: interactive exploration of chemical space [17]. Prepared pdbqt files for both target and ligands. Created in house batch file of ligands and target and docking performed in the absence of water molecules for all 26 molecules $(24+$ 2 standard molecules) [19]. The molecules were analyzsed after docking and visualized in the discovery studio for the interactions with the active site amino acids [13].

\section{RESULT AND DISCUSSION}

\section{Molecular Properties}

The molecular properties of the designed compounds 1-24 were predicted shown in Table 2. It is observed that all the compounds have significant HIA capacity as the value ranges from 78.59 to 93.80. And compounds are less permeable to Caco-2 cells with the range of values between $0.69-1.54 \mathrm{~cm} / \mathrm{sec}$. The in vivo blood brain barrier penetration values are ranged from -0.773 to 0.386 confirming them as CNS inactive compounds. The toxicity evaluation revealed that all the compounds are non-toxic in terms of mutagenicity, tumorigenicity, irritancy, hepatotoxicity and reproductive toxicity. Additionally, we have compared the above properties of designed compounds with reported PIM 1 Kinase inhibitors, SGI 1776 and AZ 1208. This over all evaluation has proved that the compounds are safer to the normal cells and suitable anti-tumor agents.

The bioactivity parameters of compounds 1-24 (Table 3) like G Protein-coupled Receptor (GPCR) Ligand property, ion channel modulator, kinase inhibitor, nuclear receptor ligand interactions, protease inhibitor and enzyme inhibitor were predicted for the designed compounds and compared with the values of SGI 1776 and AZ 1208. The results support them as safer compounds with good binding capacities and cell growth inhibitors.

The predicted Lipinski properties of 1-24 (Table 4) with valid scorings bolster and their safer drug behaviour. An orally available drug is elected to be in agreement with Lipinski's rule if the molecular weight is less than 500 Daltons, the number of hydrogen bond donors is less than 5 , the number of hydrogen bond acceptors is less than 10, the partition co-efficient $(\log \mathrm{P})$ value is less than 5 and the molecular refractivity is within the range. The results exhibit that compounds stratify to Lipinski's, so they should theoretically manifest good oral absorption. The total polar surface area was calculated and is observed that the value is less than 140 for most of the compounds. This acceptability with respect to Lipinski rule proves them as safe administrable drugs and establishes their pharmacological activity [14 and 15]. 
Table 2. Predicted molecular properties of the designed oxindole derivatives

\begin{tabular}{|c|c|c|c|c|c|c|}
\hline $\begin{array}{l}\text { Compd } \\
\text { code }\end{array}$ & $\begin{array}{l}\text { Human } \\
\text { intestinal } \\
\text { absorption } \\
(\text { HIA, \%) })^{\mathrm{a}}\end{array}$ & $\begin{array}{l}\text { In Vitro Caco-2 } \\
\text { Cell Permeability } \\
(\log \text { Papp in 10- } \\
6 \mathrm{~cm} / \mathrm{s})^{\mathrm{b}}\end{array}$ & $\begin{array}{l}\text { In Vitro skin } \\
\text { Permeability } \\
(\log \mathrm{Kp})^{\mathrm{c}}\end{array}$ & $\begin{array}{l}\text { In vitro } \\
\text { VDss } \\
\text { (human) } \\
(\log \mathrm{L} / \mathrm{kg})^{\mathrm{d}}\end{array}$ & $\begin{array}{l}\text { In vitro blood- } \\
\text { brain barrier } \\
\text { permeability } \\
(\log B B)^{\mathrm{e}}\end{array}$ & Toxicity \\
\hline 1. & 90.692 & 1.376 & -3.184 & 0.254 & 0.225 & Non toxic \\
\hline 2. & 90.527 & 1.545 & -2.67 & 0.354 & 0.269 & Non toxic \\
\hline 3. & 90.138 & 1.548 & -2.688 & 0.384 & 0.282 & Non toxic \\
\hline 4. & 91.836 & 1.364 & -3.376 & 0.762 & 0.203 & Non toxic \\
\hline 5. & 86.373 & 0.691 & -3.049 & -0.136 & -0.616 & Non toxic \\
\hline 6. & 91.997 & 1.74 & -2.607 & 0.066 & 0.356 & Non toxic \\
\hline 7. & 93.366 & 0.91 & -2.735 & -0.027 & 0.386 & Non toxic \\
\hline 8. & 92.187 & 1.49 & -3.098 & 0.477 & 0.222 & Non toxic \\
\hline 9. & 88.313 & 0.881 & -2.801 & 0.135 & -0.328 & Non-toxic \\
\hline 10. & 90.393 & 0.853 & -2.799 & 0.209 & -0.168 & Non-toxic \\
\hline 11. & 90.005 & 0.854 & -2.799 & 0.237 & -0.146 & Non-toxic \\
\hline 12. & 89.457 & 0.901 & -2.839 & 0.644 & -0.688 & Non-toxic \\
\hline 13. & 78.59 & 1.014 & -2.799 & -0.141 & -0.773 & Non-toxic \\
\hline 14. & 89.984 & 0.88 & -2.769 & -0.026 & -0.465 & Non-toxic \\
\hline 15. & 89.554 & 0.897 & -2.735 & 0.596 & -0.919 & Non-toxic \\
\hline 16. & 88.446 & 0.9 & -2.766 & 0.126 & -0.358 & Non-toxic \\
\hline 17. & 90.531 & 1.216 & -3.178 & 0.288 & 0.189 & Non-toxic \\
\hline 18. & 91.797 & 1.238 & -2.983 & 0.493 & 0.259 & Non-toxic \\
\hline 19. & 91.408 & 1.241 & -2.978 & 0.526 & 0.272 & Non-toxic \\
\hline 20. & 91.674 & 1.204 & -3.366 & 0.784 & 0.168 & Non-toxic \\
\hline 21. & 93.802 & 0.58 & -3.62 & -0.035 & -0.734 & Non-toxic \\
\hline 22. & 93.183 & 1.393 & -2.628 & 0.173 & 0.334 & Non-toxic \\
\hline 23. & 92.636 & 1.267 & -2.749 & 0.383 & 0.075 & Non-toxic \\
\hline 24. & 89.356 & 1.436 & -2.928 & 0.303 & 0.28 & Non-toxic \\
\hline SGI 1776 & 96.08 & 24.30 & -2.735 & 0.662 & 1.18 & Mutagenicity \\
\hline AZ 1208 & 96.02 & 3.11 & -2.699 & 1.168 & 0.82 & Mutagenicity \\
\hline
\end{tabular}

a. Human intestinal absorption is the sum of bioavailability and absorption values evaluated from the ratio of cumulative excretion in urine, bile and feces; b. Caco-2 cells are derived from human colon adenocarcinoma and posses multiple drug transport pathways through the intestinal epithelium; c. skin permeability is a significant consideration for many consumer product efficacy, and of interest for the development of transdermal drug delivery; d. the steady state volume of distribution (vdss) is the theoretical volume that the total dose of a drug would need to be uniformly distributed to give the same concentration as in blood plasma;e. the ability of a drug to cross into the brain is an important parameter to consider to help reduce side effects and toxicities or to improve the efficiency of drugs whose pharmacological activity is within the brain.

Collectively and based on the estimated ligand efficiency, drug likeliness and pharmacokinetic predictors, the designed compounds considered as a pharmacologically active, which can be considered on progressing further potential hits. 
Table 3. In silico predicted bioactivity properties of the designed oxindole derivatives

\begin{tabular}{|c|c|c|c|c|c|c|}
\hline $\begin{array}{l}\text { Compound } \\
\text { code }\end{array}$ & $\begin{array}{l}\text { GPCR } \\
\text { ligand }\end{array}$ & $\begin{array}{l}\text { Ion } \\
\text { channel } \\
\text { modulator }\end{array}$ & $\begin{array}{l}\text { Kinase } \\
\text { inhibitor }\end{array}$ & $\begin{array}{l}\text { Nuclear } \\
\text { receptor } \\
\text { ligand }\end{array}$ & $\begin{array}{l}\text { Protease } \\
\text { inhibitor }\end{array}$ & $\begin{array}{l}\text { Enzyme } \\
\text { inhibitor }\end{array}$ \\
\hline 1. & -0.42 & -0.86 & -0.87 & -0.92 & -0.94 & -0.28 \\
\hline 2. & -0.34 & -0.76 & -0.79 & -0.83 & -0.78 & -0.33 \\
\hline 3. & -0.28 & -0.75 & -0.75 & -0.78 & -0.75 & -0.19 \\
\hline 4. & -0.24 & -0.70 & -0.59 & -0.77 & -0.71 & -0.20 \\
\hline 5. & -0.20 & -0.87 & -0.61 & -0.69 & $\begin{array}{l}-0.39 \\
\end{array}$ & -0.21 \\
\hline 6. & -0.21 & -0.25 & -0.19 & -0.26 & -0.52 & 0.00 \\
\hline 7. & -0.15 & -0.19 & -0.06 & -0.41 & -0.45 & 0.21 \\
\hline 8. & -0.23 & -0.56 & -0.48 & $\begin{array}{l}-0.51 \\
\end{array}$ & $\begin{array}{l}-0.47 \\
\end{array}$ & -0.14 \\
\hline 9. & -0.45 & -0.81 & -0.82 & -0.78 & -0.86 & -0.36 \\
\hline 10. & -0.38 & -0.72 & -0.75 & -0.71 & -0.72 & -0.40 \\
\hline 11. & -0.35 & -0.71 & -0.74 & $\begin{array}{l}-0.70 \\
\end{array}$ & -0.71 & $\begin{array}{l}-0.29 \\
\end{array}$ \\
\hline 12. & -0.33 & -0.67 & -0.63 & -0.72 & -0.70 & -0.30 \\
\hline 13. & -0.33 & -0.82 & -0.68 & -0.70 & -0.47 & -0.29 \\
\hline 14. & -0.27 & $\begin{array}{l}-0.28 \\
\end{array}$ & -0.24 & -0.23 & -0.50 & $\begin{array}{l}-0.12 \\
\end{array}$ \\
\hline 15. & $\begin{array}{l}-0.22 \\
\end{array}$ & -0.23 & -0.12 & -0.36 & -0.43 & 0.06 \\
\hline 16. & -0.34 & -0.55 & -0.56 & -0.53 & -0.51 & -0.25 \\
\hline 17. & $\begin{array}{l}-0.40 \\
\end{array}$ & $\begin{array}{l}-0.91 \\
\end{array}$ & $\begin{array}{l}-0.83 \\
\end{array}$ & $\begin{array}{l}-0.84 \\
\end{array}$ & $\begin{array}{l}-0.91 \\
\end{array}$ & $\begin{array}{l}-0.32 \\
\end{array}$ \\
\hline 18. & $\begin{array}{l}-0.32 \\
\end{array}$ & $\begin{array}{l}-0.82 \\
\end{array}$ & -0.76 & -0.76 & -0.76 & -0.38 \\
\hline 19. & -0.28 & -0.81 & -0.73 & -0.72 & -0.73 & -0.25 \\
\hline 20. & $\begin{array}{l}-0.24 \\
\end{array}$ & -0.75 & -0.58 & -0.72 & $\begin{array}{l}-0.70 \\
\end{array}$ & -0.26 \\
\hline 21. & -0.23 & -0.91 & -0.63 & -0.67 & -0.41 & -0.26 \\
\hline 22. & -0.21 & -0.33 & -0.19 & -0.22 & -0.51 & -0.06 \\
\hline 23. & -0.15 & $\begin{array}{l}-0.28 \\
\end{array}$ & -0.06 & -0.36 & $\begin{array}{l}-0.44 \\
\end{array}$ & 0.14 \\
\hline 24. & -0.24 & $\begin{array}{l}-0.62 \\
\end{array}$ & 0.49 & -0.49 & 0.48 & -0.20 \\
\hline SGI 1776 & -0.2 & -0.27 & -0.13 & -0.2 & -0.19 & -0.21 \\
\hline AZ 1208 & -1.26 & -1.22 & -0.75 & -1.01 & -1.33 & -0.46 \\
\hline
\end{tabular}

Abbreviations: GPCRL: G protein-coupled receptor Ligand; ICM: Ion channel modulator; KI: Kinase inhibitor; NRL: Nuclear receptor ligand; PI: Protease inhibitor; EI: Enzyme inhibitor. For organic compounds, If the bioactivity score is $(>0)$, then it is active, if $(-5.0-0.0)$ then moderately active, if $(<-5.0)$ then inactive.

Table 4. In silico predicted lipinski's properties of the designed oxindole derivatives

\begin{tabular}{|c|c|c|c|c|c|c|c|}
\hline $\begin{array}{l}\text { Compound } \\
\text { code }\end{array}$ & $\begin{array}{l}\text { M.W. } \\
\text { g/mol }\end{array}$ & H.B. Don. & $\begin{array}{l}\text { H.B. } \\
\text { Acc. }\end{array}$ & 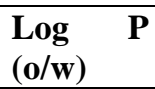 & $\begin{array}{l}\text { M.R. } \\
\mathrm{cm}^{3} / \mathbf{m o l}\end{array}$ & $\begin{array}{l}\text { TPSA } \\
\AA^{2}\end{array}$ & Lip. Vio. \\
\hline 1. & 294.44 & 1 & 1 & 2.87 & 88.85 & 89.73 & 0 \\
\hline 2. & 292.42 & 1 & 1 & 2.78 & 90.66 & 89.73 & 0 \\
\hline 3. & 306.45 & 1 & 1 & 3.06 & 95.46 & 89.73 & 0 \\
\hline 4. & 321.46 & 1 & 2 & 1.87 & 102.27 & 92.97 & 0 \\
\hline 5. & 385.52 & 1 & 4 & 1.43 & 111.24 & 135.49 & 0 \\
\hline 6. & 288.39 & 1 & 1 & 2.99 & 85.50 & 91.42 & 0 \\
\hline 7. & 289.38 & 1 & 2 & 1.61 & 83.30 & 104.31 & 0 \\
\hline 8. & 328.45 & 2 & 1 & 2.65 & 98.83 & 98.52 & 0 \\
\hline 9. & 339.43 & 1 & 3 & 1.88 & $\begin{array}{l}97.68 \\
\end{array}$ & 135.55 & 0 \\
\hline 10. & 337.42 & 1 & 3 & 1.79 & 99.48 & 135.55 & 0 \\
\hline 11. & 351.44 & 1 & 3 & 2.08 & 104.28 & 135.55 & 0 \\
\hline 12. & 366.46 & 1 & 4 & 0.88 & 111.10 & 138.79 & 0 \\
\hline 13. & 429.53 & 1 & 5 & 0.44 & 118.06 & 178.07 & 0 \\
\hline 14. & 333.39 & 1 & 3 & 2.00 & 94.33 & 137.24 & 0 \\
\hline 15. & 334.37 & 1 & 4 & 0.63 & 92.12 & 150.13 & 0 \\
\hline
\end{tabular}


Table 4 (continued). In silico predicted lipinski's properties of the designed oxindole derivatives

\begin{tabular}{|l|l|l|l|l|l|l|l|}
\hline $\mathbf{1 6 .}$ & 373.45 & 2 & 3 & 2.63 & 107.65 & 144.34 & 0 \\
\hline $\mathbf{1 7 .}$ & 308.46 & 1 & 1 & 3.32 & 93.82 & 89.73 & 0 \\
\hline $\mathbf{1 8 .}$ & 306.45 & 1 & 1 & 3.23 & 95.62 & 89.73 & 0 \\
\hline $\mathbf{1 9}$. & 320.47 & 1 & 1 & 3.52 & 100.43 & 89.73 & 0 \\
\hline $\mathbf{2 0 .}$ & 335.49 & 1 & 2 & 2.32 & 107.24 & 92.97 & 0 \\
\hline $\mathbf{2 1 .}$ & 399.55 & 1 & 4 & 1.88 & 116.20 & 135.49 & 0 \\
\hline $\mathbf{2 2 .}$ & 302.41 & 1 & 1 & 3.44 & 90.47 & 91.42 & 0 \\
\hline $\mathbf{2 3 .}$ & 303.40 & 1 & 2 & 2.07 & 88.26 & 104.31 & 0 \\
\hline $\mathbf{2 4 .}$ & 342.48 & 2 & 1 & 3.10 & 103.79 & 98.52 & 0 \\
\hline SGI 1776 & 405.42 & 1 & 7 & 4.27 & 107.95 & 54.68 & 0 \\
\hline AZ 1208 & 221.28 & 1 & 2 & 2.42 & 65.26 & 71.47 & 0 \\
\hline
\end{tabular}

\section{Molecular Docking}

The designed compounds were docked against the human PIM1 (PDB ID: 3BGQ) to predict their binding mode. The compounds were found to have binding energies in the range of -7.20 to -9.70 $\mathrm{kcal} / \mathrm{mol}$ were illustrated in Table 5. They formed 1-3 hydrogen bonds with LEU 44, LYS 67, GLU 121 and ASP 186 amino acids in the active site. In addition, different hydrophobic interactions were also observed including pi-sigma, pi-pi staked, pi-alkyl, and alkyl types with LEU 174, ILE 185, LEU 120, ALA 65, ARG 122 and PHE 49 are shown in Figure 2. Among the series, compound 16 and compound 24 are showed equivalent dock score values $(-9.7 \mathrm{kcal} / \mathrm{mol})$ which are comparable to reference compounds AZD1208 and SGI1776. Overall results demonstrating, dithiocarbamate with aromatic ring as a side chain at third position and electron with drawing (nitro) or electron releasing (methyl) on oxindole ring important for PIM1 Kinase inhibition activity.

Table 5. Binding energies and interactions between human PIM1 (PDB ID: 3BGQ) and designed oxindole derivatives

\begin{tabular}{|c|l|l|c|}
\hline Ligand & $\begin{array}{l}\text { Hydrogen } \\
\text { bond } \\
\text { Interactions }\end{array}$ & Hydrophobic Interaction & $\begin{array}{c}\text { Dock score } \\
\text { values } \\
\text { (kcal/mol) }\end{array}$ \\
\hline $\mathbf{1 .}$ & NIL & ILE:104, ALA:65 & -7.2 \\
\hline $\mathbf{2 .}$ & $\begin{array}{l}\text { GLU:121, } \\
\text { GLU:171. }\end{array}$ & $\begin{array}{l}\text { LEU:120, ILE:104, PHE:49, ILE:185, ALA:65, ILE:104, LEU- } \\
\text { GLU:171, ASN:172, VAL:52, ASP:186, LYS:67 }\end{array}$ & -8.1 \\
\hline $\mathbf{3 .}$ & GLU:121 & No Interactions & -8.4 \\
\hline & GLU:121, & $\begin{array}{l}\text { LYS:67, ILE:104, LEU:120, ILE:185, PHE:49, ILE:104, } \\
\text { LYS:67, LEU:120, ILE:185, ASP:128, LEU:4, PRO:123, }\end{array}$ & -7.9 \\
$\mathbf{4 .}$ & $\begin{array}{l}\text { GLU:171, } \\
\text { ASN:172 }\end{array}$ & $\begin{array}{l}\text { LEU:174, VAL:52, ARG:122, ALA:65, PHE:49, ASN:172, } \\
\text { 5. }\end{array}$ & GLU:121, \\
\hline $\mathbf{6 .}$ & GLU:171. & No Interactions & -8.1 \\
\hline
\end{tabular}


Table 5 (continued). Binding energies and interactions between human PIM1 (PDB ID: 3BGQ) and designed oxindole derivatives

\begin{tabular}{|c|c|c|c|}
\hline 7. & $\begin{array}{l}\text { LYS:67, } \\
\text { ASP18 }\end{array}$ & LEU:120, ILE:104, VAL:52, LEU:174, ALA:65, ILE:185 & -7.5 \\
\hline 8. & GLU:121 & ILE:104, LEU:120, ALA:65, ILE:185 & -9 \\
\hline 9. & $\begin{array}{l}\text { GLU:121, } \\
\text { LYS:67, } \\
\text { ASP:186 }\end{array}$ & ALA:65, LEU:120, ILE:185, PHE:49, VAL:52, ILE:104 & -7.9 \\
\hline 10. & $\begin{array}{l}\text { GLU:121, } \\
\text { LYS:67, } \\
\text { ASP:186 }\end{array}$ & ILE:185, VAL:52, LEU:120, ALA:65, PHE:49, ILE:104 & -8.6 \\
\hline 11. & $\begin{array}{l}\text { ASP: } 186 \\
\text { LYS: } 67\end{array}$ & ALA:65, ILE:185, VAL:52, PHE:49, LEU:120, ILE:104 & -9.1 \\
\hline 12. & $\begin{array}{l}\text { GLU:121, } \\
\text { LYS:67 } \\
\text { ASN:172, } \\
\text { ASP:186 }\end{array}$ & ILE:104, ILE:185, PHE:49, ALA:65, LEU:120, VAL:52 & -8.7 \\
\hline 13. & $\begin{array}{l}\text { ASP:186, } \\
\text { GLU:121, } \\
\text { LYS:67 }\end{array}$ & LEU:120, ILE:185, ILE:104, ALA:65, VAL:52 & -8.7 \\
\hline 14. & $\begin{array}{l}\text { GLU:121, } \\
\text { LYS:67, } \\
\text { ASP:186 }\end{array}$ & LEU:120, ILE:104, ALA:65, VAL:52, ILE:185 & -8.4 \\
\hline 15. & $\begin{array}{l}\text { GLU:121, } \\
\text { ASP:186, } \\
\text { LYS:67 }\end{array}$ & ILE:104, LEU:120, ILE:185, ALA:65, VAL:52 & -7.9 \\
\hline 16. & $\begin{array}{l}\text { GLU:121, } \\
\text { LYS:67, } \\
\text { ASP:18, } \\
\text { GLU:121. }\end{array}$ & ILE:185, ALA:65, VAL:52, ILE:104, LEU:120 & -9.7 \\
\hline 17. & GLU:121 & VAL:52, ILE:104, LEU:120, ALA:65 PHE:49, ILE:185 & -7.6 \\
\hline 18. & $\begin{array}{l}\text { GLU:121, } \\
\text { GLU:171 }\end{array}$ & PHE:49, ILE:104, VAL:52, ALA:65, LEU:120, ILE:185 & -8.6 \\
\hline 19. & GLU:121 & PHE:49, ILE:104, ILE:185, VAL:52, ALA:65, LEU:120 & -9 \\
\hline 20. & $\begin{array}{l}\text { ASP:186, } \\
\text { GLU:121, } \\
\text { GLU:171, } \\
\text { ASN:172, }\end{array}$ & ILE:104, ILE:185, PHE:49, LEU:120, ALA:65, VAL:52 & -8.6 \\
\hline 21. & $\begin{array}{l}\text { GLU:121, } \\
\text { GLU:171 }\end{array}$ & ILE:104, ILE:185, LEU:120, VAL:52, ALA:65 & -8.7 \\
\hline 22. & $\begin{array}{l}\text { GLU:121, } \\
\text { GLU:171 }\end{array}$ & VAL:52, ALA:65, ILE:104, LEU:120, ILE:185 & -8.6 \\
\hline 23. & $\begin{array}{l}\text { GLU:121, } \\
\text { GLU:171 }\end{array}$ & ILE:104, ALA:65, LEU:120, ILE:185 & -8.2 \\
\hline 24. & GLU:121 & ALA:65, LEU:120, ILE:104, VAL:52, ILE:185 & -9.7 \\
\hline $\begin{array}{l}\text { SGI- } \\
1776\end{array}$ & $\begin{array}{l}\text { LYS:67, } \\
\text { GLU:121, } \\
\text { ASP:128, } \\
\text { GLU:171 }\end{array}$ & $\begin{array}{l}\text { ILE:185, ILE:104, LEU:120, ALA:65, VAL:52, PHE:49, } \\
\text { LEU:44, ARG:122, LEU:174, ILE:185, LEU:120. }\end{array}$ & -10.1 \\
\hline $\begin{array}{l}\text { AZD- } \\
1208\end{array}$ & LEU:44 & $\begin{array}{l}\text { VAL:52, ALA:65, ARG:122, LEU:174, VAL:126, LEU:44, } \\
\text { LEU:174, LEU:120, ILE:185, LYS:67 }\end{array}$ & -9.7 \\
\hline
\end{tabular}



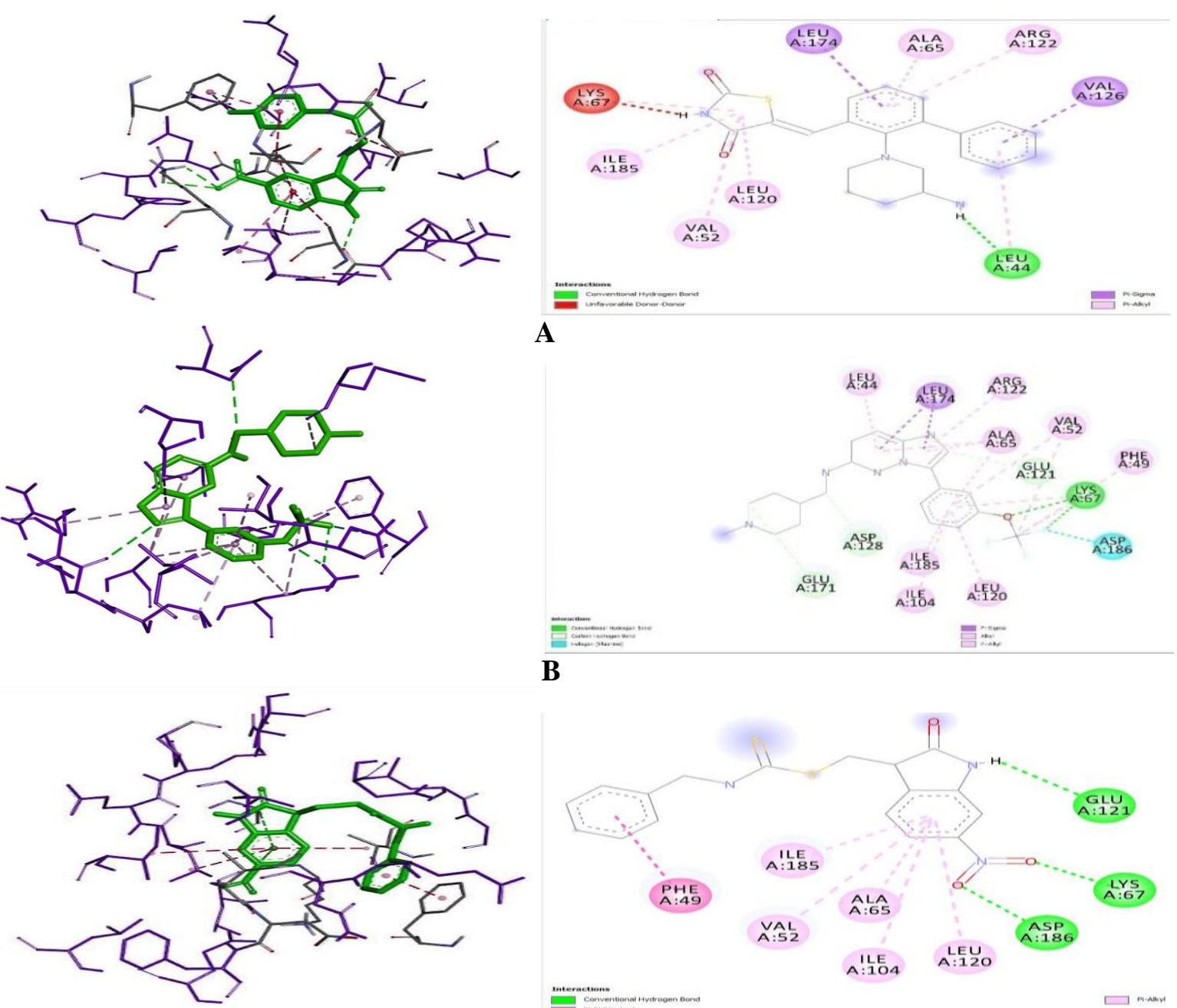

$\mathbf{B}$
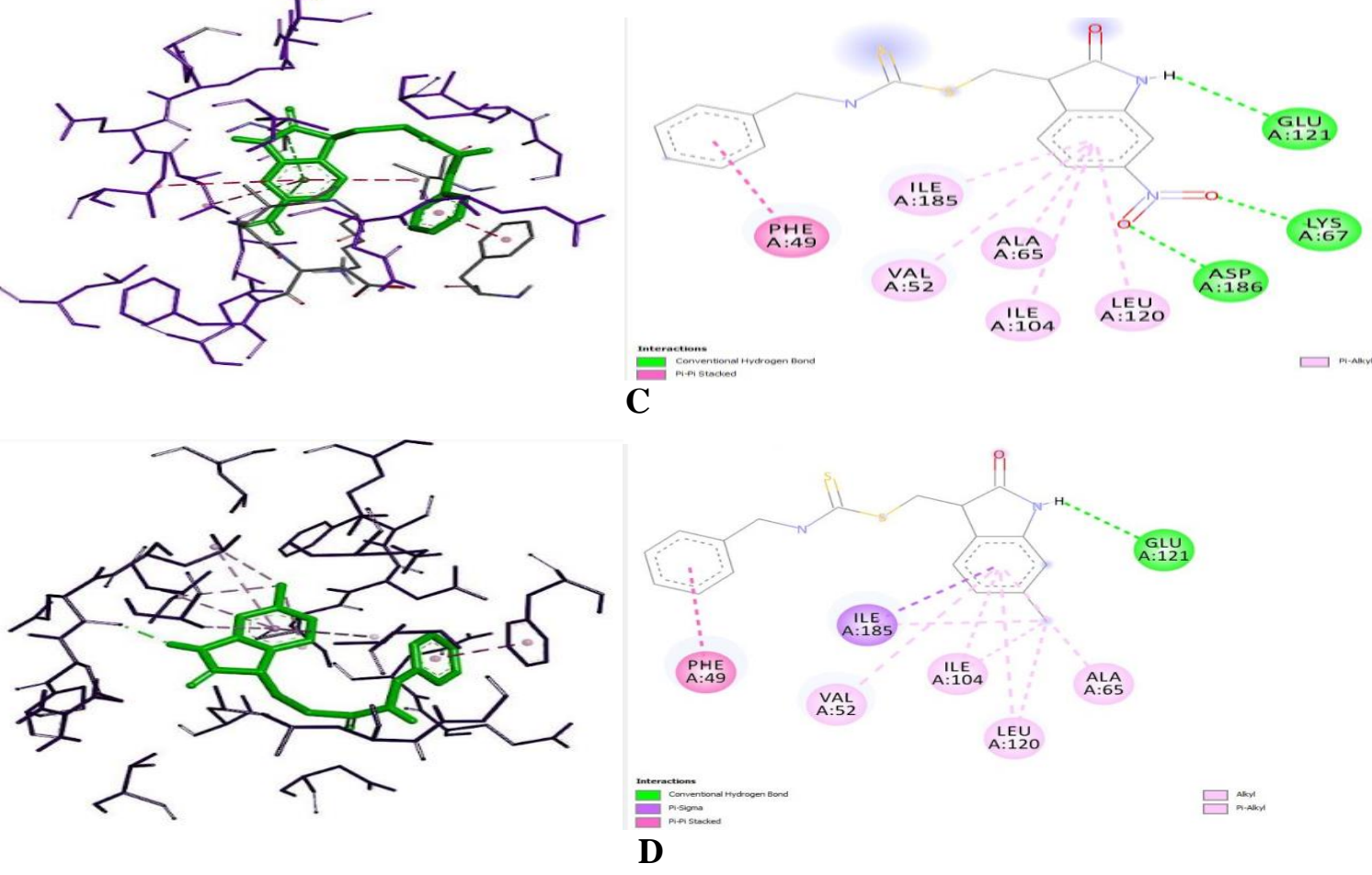

Figure 2. The 3D and 2D docking mode of ligands (A) AZD1208 (B) SGI1776 (C) Compound 16 (D) Compound 24, into PIM1 Kinase (pdb code: 3BGQ) showing hydrogen bonds (-), hydrophobic interactions $(--\infty)$

PIM (Pro-viral integration site in Moloney murine leukemia virus) kinases are a family of serine/threonine protein kinases that are identified as unique molecular targets in oncogenesis and highly expressed in numerous human cancers. In connection with literature, a new series of 2-oxindole based 
dithiocarbamate derivatives was designed and performed in silico experiments. The drug-likeliness assessment analysed with Molinspiration, Molsoft, Swiss ADME and pkCSM softwares, which elucidated their full compliance with Lipinski's rule, physicochemical properties and pharmacokinetic parameters. Further molecular docking study showed good binding energy for all the compounds with the human target protein PIM1 (3BGQ). Overall, the ligands 16 and 24 exhibited the equivalent binding energies of $-9.7 \mathrm{kcal} / \mathrm{mol}$ when compared to known reference compound AZD1208 (-9.7 kcal/mol). These results suggested that this study will help in designing of novel derivatives of dithiocarbamate substituted 2-oxindole in discovery of new chemical entities for anticancer therapy.

\section{ACKNOWLEDGEMENTS}

The authors are thankful to the Principal and Management of Sarojini Naidu Vanitha Pharmacy Maha Vidhyalaya, Osmania University, Hyderabad, India, for providing research facilities.

\section{AUTHOR CONTRIBUTIONS}

Concept: S.J.T.; Design: M.S.S.; Control: S.J.T.; Sources: S.J.T.; Materials: -; Data Collection and/or processing: D.A., D.K.B.; S.B., P.C.; Analysis and/or interpretation: P.C., J.C.; Literature review: D.A., D.K.B., S.B., P.C., J.C.; Manuscript writing: M.S.S, D.A., D.K.B, S.B., P.C., J.C., S.J.T.; Critical review: M.S.K., S.J.T.; Other: -

\section{CONFLICT OF INTEREST}

The authors declare no conflict of interest.

\section{ETHICS COMMITTEE APPROVAL}

The authors declare that the ethics committee approval is not required for this study.

\section{REFERENCES}

1. Zhang, X., Song, M., Kundu, J.K., Lee, M.H., Liu, Z.Z. (2018). PIM Kinase as an executional target in cancer. Journal of Cancer Prevention, 23(3), 109-116. [CrossRef]

2. Tursynbay, Y., Zhang, J., Li, Z., Tokay, T., Zhumadilov, Z., Wu, D., Xie, Y. (2016). PIM kinases as cancer drug target: An update (Review). Biomedical Reports, 4(2), 140-146. [CrossRef] 
3. Saurabh, K., Scherzer, M.T., Shah, P.P., Mims, A.S., Lockwood, W.W., Kraft, A.S. (2014). The PIM family of oncoproteins: small kinases with huge implications in myeloid leukemogenesis and as therapeutic targets. Oncotarget, 5, 8503-8514. [CrossRef]

4. Asati,V., Mahapatra, D.K., Bharti, S.K. (2019). PIM kinase inhibitors: Structural and pharmacological perspectives. European Journal of Medicinal Chemistry, 172, 95-108. [CrossRef]

5. Harshita, P.S., Soma Yasaswi, P., Jyothi, V., Saritha Jyostna, T. (2020). PIM-1 kinase: a novel target for cancer chemotherapy-a review. International Journal of Pharmaceutical Sciences and Research, 11(6), 1000-1011. [CrossRef]

6. Roskoski, R., Sunitinib, A. (2007). VEGF and PDGF receptor protein kinase and angiogenesis inhibitor. Biochemical and Biophysical Research Communications, 356(2), 323-328. [CrossRef]

7. Clinical trails web site. From https://www.clinicaltrials.gov/

8. Baig, M.H., Ahmad, K., Adil, M., Khan, Z.A., Khan, M.I. (2014). Drug discovery and in silico techniques: A mini-review. Enzyme Engineering, 4(1), 123. [CrossRef]

9. Daina, A., Michielin, O., Zoete, V. (2017). SwissADME: a free web tool to evaluate pharmacokinetics, drug-likeness and medicinal chemistry friendliness of small molecules. Scientific Reports, 7(3), 427-417. [CrossRef]

10. Abagyan, R.A., Totrov, M.M., Kuznetsov, D.N. (1994). ICM - a new method for protein modeling and design. Applications to docking and structure prediction from the distorted native conformation. Journal of Computational Chemistry, 15(5), 488-506. [CrossRef]

11. Molinspiration Cheminformatics free web site. From https://www.molinspiration.com/

12. Pires, E.V.D., Blundell, L.T., Ascher, B.D. (2015). pkCSM: Predicting Small-Molecule Pharmacokinetic and Toxicity Properties Using Graph-Based Signatures. Journal of Medicinal Chemistry, 58(9), 4066-4072. [CrossRef]

13. Klejborowska, G., Urbaniak, A., Maj, E., Preto, J., Moshari, M., Wietrgyk, J., Tusuzynski, J.A., Chambers, T.C., Huczyriski, A. (2020). Synthesis and biological evaluation and molecular docking studies of new amides of 4- chlorothiocolchicine as anticancer agents. Bioorganic Chemistry, 97, 103664. [CrossRef]

14. Agata, S., Tomasz, P., Joanna, S., Paweł, S., Aleksandra, S. (2014). Molecular properties prediction, docking studies, and antimicrobial screening of 1,3,4-thiadiazole and s-triazole derivatives. Current Computer-Aided Drug Design, 10(1), 3-14. [CrossRef]

15. Farrang, A.M., Ibrahim, M.H., Mehany, A.B.M., Ismail, M.M.F. (2020). New cyanopyridine based scaffold as PIM1 inhibitors and apoptotic inducers: Synthesis and SARs study. Bioorganic Chemistry, 105, 104378. [CrossRef]

16. Protein Data Bank (PDB) web site. From https://www.rcsb.org

17. Pharmit: interactive exploration of chemical space web site. From https://pharmit.csb.pitt.edu.

18. AutoDockVina. v.1.2.0, the free GUI for AutoDock Vina web site. From http://autodock.scripps.edu/ 
19. Muni Sireesha, S., Dipankar, B., Soujanya, D., Brijitha, G., Jyothi, V. (2021) Computational validation of tacrine analogs as antialzheimer's agents against acetylcholinesterases. International Journal of Biology, Pharmacy and Allied Sciences, 10(10), 243-254. [CrossRef] 